\title{
Legal Protection for Domestic Airlines Consumers related with Ticket Purchasing
}

\author{
Thomas Heru susanto ${ }^{1}$, Ahmadi Miru ${ }^{2}$, Winner Sitorus ${ }^{3}$ \\ ${ }^{1}$ Post Graduate of Hasanuddin Univeristy \\ ${ }^{2}$ Law Faculty of Hasanuddin Univesity \\ ${ }^{3}$ Law Faculty of Hasanuddin University
}

\begin{abstract}
This research aims to know legal protection for consumer toward Bid Price and Ask Price of Airline Ticket Purchasing based on Ministry of Transportation No. PM 14, 2016. This research is a normative law research by using case approach in form of field research. Research result shows legal protection for consumer toward Bid Price and Ask Price of Airline Ticket Purchasing are arranged on Ministry of Transportation No. PM 78, 2017, that airlines who do violation toward bid price of airline shall be punished. In its implementation, there is no one gotten the punishment, even though there are violations found toward the bid price of airline regulation in Manokwari. Legal effort for consumer is on airline ticket price which is not appropriate with Ministry of Transportation No. 14 PM, 2016 can submit information or report complain from society to department of industry and commerce or Civil Society Organization which run in consumer protection sector. Compensation which is eligible to be accepted, if airline is proved to determined the price out of bid price on their airlines' service is material compensation in form of proper price range and immaterial loss in form of interest from material loss which is suffered by the consumer.
\end{abstract}

Keywords: Consumer Protection; Ministry of Transportation; Transportation.

\section{ABSTRAK}

Penelitian ini bertujuan untuk mengetahui perlindungan hukum bagi konsumen terhadap Penerapan Batas Atas dan Batas Bawah Pembelian Tiket Pesawat berdasarkan Peraturan Menteri Perhubungan Nomor PM 14 Tahun 2016. Penelitian ini merupakan penelitian hukum normatif dengan menggunakan pendekatan kasus (case approach) dalam bentuk penelitian lapangan (field research). Hasil penelitian menunjukkan perlindungan hukum bagi konsumen terhadap Penerapan Batas Atas dan Batas Bawah Pembelian Tiket Pesawat pada dasarnya telah diatur dalam Peraturan Menteri Perhubungan Nomor PM 78 Tahun 2017, bahwa maskapai yang melakukan pelanggaran terhadap ketetapan batas atas tarif maskapai penerbangan dapat dijatuhi sanksi. Dalam implementasinya, belum ada yang diberikan sanksi, meskipun telah ditemukan adanya pelanggaran terhadap aturan tentang batas atas tarif jasa penerbangan di Manokwari. Upaya hukum bagi konsumen dalam hal terdapat harga tiket pesawat yang tidak sesuai dengan Peraturan Menteri Perhubungan Nomor PM 14 Tahun 2016 yakni dapat 
memberikan informasi atau laporan pengaduan dari masyarakat kepada dinas perindustrian dan perdagangan atau lembaga swadaya masyarakat yang bergerak dibidang perlindungan konsumen. Ganti kerugian yang berhak diterima apabila terbukti terdapat maskapai jasa penerbangan yang menetapkan tarif di luar ketentuan batas atas taris jasa penerbangan adalah ganti kerugian materil berupa selisih harga yang seharusnya dan kerugian imateril berupa bunga atas jumlah kerugian materil yang diderita konsumen.

Kata Kunci: Perlindungan Konsumen; Menteri Perhubungan; Transportasi.

Citation: Susanto, T.H., Miru, A., Sitorus, W. "Legal Protection for Domestic Airlines Consumers Related with Ticket Purchasing." Mulawarman Law Review 4, no. 1 (2019)

\section{INTRODUCTION}

Transportation becomes media of human or goods moving from one place to another by using a transportation which is moved by human, animal or machine. Airlines has very important role to improve activity in Indonesia. Indonesia is a country which consist 17.508 islands, and choice for airlines usage is the fasted and precise method to travel to a place. ${ }^{1}$ Industry of Airline service in Indonesia experiences fast development, by year. From data in Directorate General of Civil Aviation, was recorded that in 2017 there were 15 airlines who active to server consumers in Indonesia. Nowdays, cheap ticke is one of variable which is corcernd by the society. Unfortunately, occasionally security and convinience of airlines are often to be skiped by the airlines, in fact air security risk must be priority to be minimized. Airlines reduce operation cost to sell ticket with cheap price. This condition indicates airlines do not corcern the passangers' safety factors, for example by reducing their fleet mantenaince. ${ }^{2}$ Meanwhile the mantenaince on airplane is an obligation for airlines fluency. Light damage on airplane can cause fatal and surely it can be tolerated.

In aviation the compliance of high safety standard is an absolute. Aviation safety implementation required to be done on all sectors, on airlines, airport, navigation, maintenaince and improvement also with training related with International Civil Aviation Organization (ICAO) regulation. ${ }^{3}$ The last several years may domestic airline companies appeared, some people who are profited and some people are not. Occasionally sudden change occurs related with airline rates which are varied and increased in several airports in Indonesia. ${ }^{4}$ It shows that airplane transportation grows rapidly. Recently many airlines search strategy to increase tickets' price especially on

\footnotetext{
${ }^{1}$ Abdul Kadir Muhammad, Hukum Pengangkutan Darat, Laut, Dan Udara. Bandung: PT Citra Aditiya Bakti, 2001, Hal. 21.

${ }^{2}$ Tim Penulis, Analisis Dan Evaluasi Hukum Tertulis Tentang Ketentuan-Ketentuan Hukum Yang Berkenaan Dengan Penentuan Jumlah Ganti Rugi Dalam Bidang Pengangkutan Udara, Jakarta: Badan Pembinaan Hukum Nasional Departemen Kehakiman, 2013, Hal. 22.

${ }^{3}$ R. Subekti, Tanggung Djawab Pengangkut Dalam Hukum Udara Indonesia, Bandung: Eresco, 2002, Hal. 31.

${ }^{4}$ Hidayat, M. T. (2017). Perlindungan Hukum Terhadap Pengguna Jasa Angkutan Udara Dalam Perspektif Peraturan Perundang-undangan Tentang Penerbangan. Al Adl: Jurnal Hukum, 8(3).
} 
holiday. Tickets' price on holiday often increases high, it can be increased up to 4 times from normal price Rp 400 thousands - to Rp 1.6 millions. It has potency of bid price violation by airline companies by raising tickets' price with maximum limit which is determined by the government on Ministryy of Transportation No. PM 14, 2016 about Determination of Bid Price and Ask Price for Economy class passengers on Domestic Commercial Airline (furthermore it is written on Ministry of Transportation Regulation No. PM 14, 2016). In this condition consumers are aggrieved and only upper class who can use airlines. It is according to Article 3 about realizing an aviation operation which is disciplined, well organized, safe, secured, comfortable, with reasonable price, and avoiding unhealthy practices of business competition, then it is needed legal foundation which manages and bind about reasonable tickets' price, to make consumers of airline will be not aggrieved. Based on it, legal provision for consumers to get reasonable tickets' price according to bid price which is determined its ideal can be protected through supervision that is done by the government.

Law enforcement toward this violation, it needs to be important issue for the government not only toward bid price determination, but it includes ask price. From aspect of consumers' protection, ask price violation is meant to minimize airplane accident No.s, it can be big accidents or small accidents which are techical can cause flight schedule disturbance. To keep maintenance quality and punctuality, it is required much cost then airlines cost in operation and maintenance which are sourced by ticket purchasing result must be determined its minimum requirements. Ignorance of this violation, it is same with ignoring passenger safety aspect. While from protection aspect for entrepreneurs, ask price determination is in order to avoid monopoly which will be end with unfair business competition. Therefore, this rate is not only important for consumer theirselves, but it is also very important to protect airline businessmens.

\section{RESEARCH METHOD}

The research is a research of normative law ${ }^{5}$ by using case approach in form of field research ${ }^{6}$ which is research by collectiong data directly from Manokwari Rendai Airport as one of airport teritorially obeys Ministry of Transportation Regulation No. PM 14, 2016. Data which are obtained by inductive method then it is generalized and anlyzed with normative and socio-juridical approach through interview to collect data and to obtain the conclusion. This reserch is done on government department and private company of airlines service provider; Transportation Department of West Papua Province; Department of Industry and Commerce of West Papua Province;

\footnotetext{
${ }^{5}$ Irianto, Sulistyowati \& Shidarta "Metode Penelitian Hukum: Konstelasi \& Refleksi", Jakarta: Yayasan Obor Indonesia, 2011, Hal. 142

${ }^{6}$ Peter Machmud Marzuki, Penelitian Hukum, Yuridika, Vol.16, No.2, Maret 2001, hal.103.
} 
Sriwijaya Air Company Office of Manokwari; and Lion Air Company Office of Manokwari.

Legal Protection for Consumers Toward Bid Price and Ask Price of Airplane Tikcets Purchasing

One of the fastest, most efficient, proper and safety for transportation inter island or continent, airlines becomes transportation which is used by many indonesia people with island geographical condition. Facilities and infrastructure urgency in Indonesia make many entrepreneurs want to invest in transportation sector, especially airlines. With World Trade Organization Ratification/ General Aviation Training \& Testing Service (WTO/GAATS) by Indonesia, then since then Government of Indonesia is not legalized to do monopoly in company especially for airlines service. It makes many entrepreneurs start to establish airlines companies. ${ }^{7}$ Many airlines in Indonesia trigger competition among the airlines. Airline competes to take market share and to obtain the profit as big as possible. The airlines arrange the marketing strategy well, one of it is by selling chep ticket. It can be avoided that tickets price is big attractiveness for consumers.

Based on author interview with Thosia Urayama as District Manager of Batik Air on 14 September, relation with this issue that several low cost carriers (LCC), airline offers cheap price because company decrease the operation cost. It is known that company operational cost is very big and is important aspect in aviation and related direcly with flight service and safety. One of operational example is avtur cost and airplane maintenance cost. In writer point of view, producers or businessman will find the highest profit according to economic principle. In order to obtain the highest profit, producers must compete with other entrepreneurs with their business act that can harm consumers. The strict of competition can change behavior to unfair business competition because businessman has cross importance among them. This fair competetition on its turn can harm the consumers.

In rate determination airline should put balance forward between consumers importance and entrepreneurs importance. Through bid price government struggle to give protection to airline user to protect them from unreasonable price by airlines provider, whereas ask price is a government effort to sustain business and prevent unfair business competition, ask price indirectly gives protection to consumers. Through ask price then it is sure

${ }^{7}$ Kurniawan, K. (2012). Permasalahan dan Kendala Penyelesaian Sengketa Konsumen melalui Badan Penyelesaian Sengketa Konsumen (Bpsk). Jurnal Dinamika Hukum, 12(1), 160-172. 
company sells ticket with precise rate and it does not burden the airlines, which is meant as precise rate is rate which is offerred by service provider must be reasonable by determining all cost which is obligated according to valid regulation such as, rate of distance, tax, insurance, and surcharge. Therefore which is meant no to burden airlines by precise rate, no cost which must be ignored to cover other component as impact from rate which is offered to cover all cost component which is required in a flight.Airline rates regulation in Indonesia is expected to be better, detail, transparent and according to airline rate regulation philosopy which is to balance consumers importance and entrepreneurs importance. Even though may regulations amended especially in 2014 but it done in order to create reasonable price, to prevent unfair business, and to create airline consumers protection especially on safety, security, and comfortability. Govenment in order to determine rate regualations becomes better, detail and transparent can be seen on a) There are provision about rate calculation component based on rate of distance, tax, insurance fee, and surcharge; b) Bid price determination, reference reate, percentage determination of ask price and on the last regulations in 2016 was made calculation in detail and transparent about bid price and ask price for every flight route. All rates always consider condition of economy, social, and politic such as rupiah value fluctuation and airplane operational cost related with avtur price, airplane spareparet and etcetera; c) Rate implementation based on group service which is full services (as high as $100 \%$ from maximum rate), medium services (as high as $90 \%$ from maximum rate), and frills (as high as $85 \%$ from maximum rate). Government through Ministry of Transportation (Kemenhub) decrease airline ask price to be $30 \%$ from the previous $40 \%$. Whereas bid price is increased $10 \%$. Its provision is in Ministry of Transportation Regulation No. PM 14, 2016 about calculation of formulation mechanism and determination of bid price and ask price on economy class passenger of domestic commercial flight.

Ministry of Transportation Regulation No. 14, 2016 about calculation of formulation mechanism and the determination of bid price and ask price on economy class passenger of domestic commercial flight will replace Ministry of Transportation Regulation No. PM 51, 2014 about Calculation of Formulation Mechanism and the Determination of Bid Price and Ask Price on Economy Class Passenger of Domestic Commercial Flight.In author's point of view, even though ask price decreases, Ministry of Transportation guarantees airline fulfills safety regulation requirements through supervision function. Beside control on airline money report, it is different with ask price is decreased, airline bid price increases $10 \%$. Considering the chaning toward exchange value and other component price which causes airplane operation cost the 
least $10 \%$ on three months in a row. As result is limit price will be appropriate. On the other side, eight airlines are endangered to be prohibited to operate.

These eight airlines did not fulfill the requirements of total airplane ownership and mastery which are arranged in Law No. 1, 2009 about Aviation. According to Law No. 1, 2009 scheduled commercial air transportation shall own at least 5 (five) unist of aircrafts and possess at least 5 (five) units of aircrafts of the type(s) suitable for supporting its business sustainability in accord with the routes served. Whereas minimum requirement No. of non-scheduled commercial air transportation shall at least own 1 (one) unit of aircraft and possess at least 2 (two) units of aircrafts. Stateowned enterprises based on service type that shows rate arrangenment gives protection toward consumers' right where Article 4 Section B of Law of Consumers' Protection mentions that consumers has right to choose and obtain goods/services according to exchange value and condition along with guarantee which is appointed. Based on author with rate system based on service type makes airline users' right are more protected to obtain service according to value which they are paid. All policy about those rates are according to consumers' right principles as follows benefit principle, justice principle, balance principle, security principle, and consumers' safety, and legal provision principle. It is result from author toward several airlines' rate on August 2018.

Table 1. Flight Rate Manokwari-Makassar

\begin{tabular}{clcccc}
\hline No & \multicolumn{1}{c}{ Name } & Destination & Airlines & Tickets' Price & Bid Price \\
\hline 1 & Taufik Hidayat & Makassar & Batik & 1.200 .000 & 2.426 .000 \\
2 & Pangat & Makassar & Sriwijaya & 1.258 .000 & 2.426 .000 \\
3 & Teguh Budi & Makassar & Batik & 1.200 .000 & 2.426 .000 \\
4 & Suwarni & Makassar & Batik & 1.426 .000 & 2.426 .000 \\
5 & Ranny & Makassar & Batik & 2.100 .000 & 2.426 .000 \\
6 & M. Arif & Makassar & Batik & 1.200 .000 & 2.426 .000 \\
7 & Said & Makassar & Batik & 1.400 .000 & 2.426 .000 \\
8 & Septon Sayori & Makassar & Sriwijaya & 1.140 .000 & 2.426 .000 \\
9 & Ibu Rita & Makassar & Sriwijaya & 1.200 .000 & 2.426 .000 \\
10 & Maria R & Makassar & Batik & 1.379 .000 & 2.426 .000 \\
11 & Onansi & Makassar & Sriwijaya & 1.380 .000 & 2.426 .000 \\
12 & Gatot H.S & Makassar & Batik & 2.200 .000 & 2.426 .000 \\
13 & Ignatius Ever & Makassar & Batik & 2.200 .000 & 2.426 .000 \\
14 & Umar & Makassar & Sriwijaya & 1.379 .000 & 2.426 .000 \\
\hline
\end{tabular}

Source: Secondary Data, August 2018. 
Table 2. Flight Rate Manokwari-Jakarta

\begin{tabular}{clllrc}
\hline No & Name & Destination & Airlines & Tickets Price & Bid Price \\
\hline 1 & Gatot Nugroho & Jakarta & Batik Air & 2.186 .000 & 4.444 .000 \\
2 & Pery Kenandi & Jakarta & Batik Air & 2.300 .000 & 4.444 .000 \\
3 & Jery & Jakarta & Batik Air & 2.186 .000 & 4.444 .000 \\
4 & Martinus Y & Jakarta & Batik Air & 1.300 .000 & 4.444 .000 \\
5 & Dina Udia W & Jakarta & Batik Air & 2.186 .000 & 4.444 .000 \\
6 & Herlina Budhy & Jakarta & Batik Air & 1.800 .000 & 4.444 .000 \\
7 & Rismarno & Jakarta & Batik Air & 1.850 .000 & 4.444 .000 \\
8 & Wisnu H & Jakarta & Batik Air & 2.870 .912 & 4.444 .000 \\
9 & Yosep Teguh & Jakarta & Batik Air & 2.800 .000 & 4.444 .000 \\
10 & Steven & Jakarta & Batik Air & 2.800 .000 & 4.444 .000 \\
\hline
\end{tabular}

Sumber: Secondary Data, August 2018.

If we corcern the whole table about, then none of airlines which determine airline service price over the maximum limit. It is because the research which author did was on august 2018, where there were not holiday or national holiday which cause ticket became expensive. Therefore, authors did preliminary research on Desember in 2017, where authors experienced that tickets which were determined far from maximum rate (Table 3).

Table 3. Flight Rate Manokwari-Makassar

\begin{tabular}{|c|c|c|c|c|c|}
\hline No & Name & Destination & Airlines & $\begin{array}{l}\text { Tickets } \\
\text { Price }\end{array}$ & Bid Price \\
\hline 1 & Thomas Heru S & Makasar & Sriwijaya Air & 4.856 .000 & 2.426 .000 \\
\hline
\end{tabular}

Source: Secondary Data, December 2017.

Calculation principle in order to determine tickets' price are distance, time, and avtur's price. Based on economic law tickets' price increaseament even though its increasing is still reasonable based on legal division of Sriwijaya. Until now, there is none complains related with tickets price increaseament. ${ }^{8}$ General Manager of Garuda Manokwari Agency ${ }^{9}$ states that rate calculation which is accepted from HO, based on Ministry of Trasnportation regulation with the routes served. On holiday their management did not ever increase the rate, because ask price or bid price on low season was also published.

\footnotetext{
${ }^{8}$ Based on author interview with Thosia Urayama, district manager of Sriwijaya Airline on 11 September 2018.

9 Based on author interview with Firman Nasar as General Manager of Garuda Airline branch Manokwari on 10 September 2018.
} 
According to Ministry of Transportation No. PM 14, 2016 and rate determination their management refers to that regulation. Garuda ticket making used system GA systematically and had electronic quality, as the result that price outside of system which was published, therefore all of it was done manually and was done by an individual outside of Garuda. Authors also did interview with Seno Pambianto as Batik Air office representative in Manokwari on 14 September 2018, its conclusion proposed that Ministry of Transportation Regulation No. 14, 2016 arrange tickets price. The price increasement done was on limit which is arranged by that regulation. Tickets increasement factors is according to Ministry of Transportation Regulation No. PM 14, 2016, then we can be responsible for all related with tickets price which is purchased in Official Lion Group office.

The issuance of Ministry of Transportation No. PM 14, 2016 about Bid Price and Ask Price of Flight Ticket Purchasing are one of government role to give protection toward airlines consumers. In that provision is determined penalty for airlines service on its essence is prohibited to sell ticket under ask price or over the bid price. It is clear its issuance of Ministry of Transportation No. PM 14, 2016 about Calculation of Mechanism Formulation and The Determination of Economy class passengers on Domestic Commercial Airline. Based on that provision, it is clear that government struggle to protect airline consumers from unreasonable price by the airlines. If there are still airline which applies cheaper ticket under the ask price means that airline violates provision about rate and it is considered can fulfill operational cost and service with minimum cost. Consumers always have tendency to choose cheap price and consumer cannot be punished if they buy ticket under the ask price, but airlines must be responsible toward ticket selling for economy class passenger which is done by themselves or ticket selling partner. Consumers who bought ticket under the ask price still have the same right with other airline's consumers, it is because of consumer who bought ticket did transportation agreement with airlines. Agreement produces right and obligation for both sides, as the result is airlines has obligation to fulfill those consumer rights. Shortly, it can be concluded that consumers who bought ticket under the ask price has same law protection right with the other customers generally.

Consumer protection is all effort to guarantee law punctuation to give protection to consumers. ${ }^{10}$ Based on that explanation then element from consumers right is an effort to guarantee the law punctuation. Law protection for the passengers in flight elements itself consist of safety, security, service,rate, and agreement. Airline's consumer protection will be fulfilled if all consumers right in this case is service user fulfilled right in Law No. 8, 1999 about Consumers Protection and Law No. 1, 2009

\footnotetext{
${ }^{10}$ Pasal 1 Angka 1 Undang-Undang Nomor 8 Tahun 1999 tentang Perlindungan Konsumen
} 
about Aviation. Beside that, to create consumers protection on airline is required arrangement, coaching, and deep supervision especially on safety, security, comfortability, service, rate, and agreement elements but in fact, in Indonesia protection toward airline's customers especially who bought ticket under the ask price cannot be fulfilled maximally or it is not fit with what was determined by Consumers protection laws and Aviation Law.

Airline, especially airline based on LCC often ignore consumers right because of safety, security, service, and comfortability. For example in service and comfortability were often met stolen luggage, slow service, and room temperature did not fulfill standard. Whereas in safety and security, there were cases such as less perform of pilot and cabin crew to run their job and then it could risk fligh safety and there were airlines which phrohibited to bring extra fuel, in fact extra fuel was required on bad weather. Airline rate arrangement in Indonesia becomes better, detail, clear and it is according to philosopy of airline rate arrangement to balance consumers importance and entrepreneurs importance. Even though many changing occur especially in 2014 but it is done in order to create reasonable rate, to prevent unfair business competition, and to create protection toward airline's consumers in safety, security, and comfortability. Government to determine regulation about rate becomes better, detail and clear can be seen from provision about component of rate calculation based on distance, tax, insurance, and surcharge rate; Bid price determination, reference rate, ask price percentage determination and on the last regulation in 2016 is made calculation in detail and clear about bid price and ask price for every flight route; and rate determination based on service group which is give by domestic commercial airlines as follows benefit principle, justice principle, balance principle, security principle, and consumers' safety, and legal provision principle. Passenger who bought ticket under the ask price still have the same right with other airline's consumers, benefit principle, justice principle, balance principle, security principle, and consumers' safety, and legal provision principle, but in fact consumers did not get maximum protection for their rights.

\section{Legal Effort for Consumers and Compensation for Consumers}

Based on Article 62 Paragraph (1) Consumers' Protection is determined that entrepreneurs who violate the provision shall face a maximum criminal penalty of 5 (five) years imprisonment or a maximum fine of $\mathrm{Rp}$. 2000,000,000,- (two billion rupiah) according to technical instruction on regulation No. 35/M.DAG/PER/7/2013. Violation toward bid price and ask price of flight ticke are arranged in Miniter of Transportation Regulation No. PM 14, 2016, apabila pada permasalahan ini berbentuk kerugian bagi 
konsumen, maka di atur dalam pasal 10. jo if on this issue harm the consumers, then it is arranged in article 10. Jo. Article 62,63 Law No. 8, 1999 about Consumers Protection shall face a maximum criminal penalty of 5 (five) years imprisonment or a maximum fine of Rp. 2000,000,000,- (two billion rupiah) and punishment in form of compensation for consumers by airline or etrepreneurs/ related airlines. ${ }^{11}$

All this time, government tends to be passive to give protection for the consumers. Whereas consumers know and understand less about what are their rights. Related with that compensation, basically it is arrangement which does not protect consumers, because it requires long process and makes consumers tends to ignore the violation toward their rights, therefore the loss is not big. Therefore for the loss is not with compensation demand for consumers because of violation toward airlines bid price must be represented in a group or class action sued, whether the initiation is by government or civil society organization which run in consumers protection sector.

Based on Wirdjono Prodjodikoro loss must be explained widely not only about wealth but also about other importances of human being such as body, soul, and somebody's honor. In law is known with two loss classifications ${ }^{12}$, material loss which is real loss that is accepted by applicant on the other day or loss from benefit loss which possible to be accepted by the applicant on the other day. Based on immaterial loss in form of interest for consumers fund are precipitated during law enforcement process. Its related with consumers loss in this research, norms violation which are meant by Nieuwenhuis here is an act of violation, where airlines management determine tickets price is out of bid price. If we review deeply, loss is a relative explanation which bases on a comparison between two conditions. Loss is range (loss range) between condition which appears as norms violation, and situation should be appear if that norms violation does not occurred. Furthermore Nieuwenhuis says to be careful to describe loss as differences between before and after law violation act. ${ }^{13}$

Loss explanation is formed by comparison between real situation (how is the real wealth as norms violation result) with hypotesis situation (that situation will be how if norms violation does not happen). Therefore it can be pulled a formula about loss is situation where one's wealth decreases thtat is caused from a engagement (through agreement or law) because norms violation by other party. ${ }^{14}$ According to Article 19

11 Berdasarkan hasil wawancara penulis dengan Adrian O.M. Atakupan selaku Staff Dinas Perindurstrian dan Perdagangan yang menangani perlindungan dan sengketa konsumen, pada tanggal 14 September 2018.

${ }^{12}$ Wirjono Prodjodikoro, Perbuatan Melanggar Hukum, Vorkink-Von Hoeve, Bandung hal.20-21.

${ }^{13}$ Ibid.

${ }^{14}$ Civil Code Article 1246: Compensation of costs, damages and interests that the creditor may claim comprises of losses he had suffered and profits he would have enjoyed, subject to the limitations or modifications stipulated hereunder 
Paragraph (1) No. 8, 1999 about Consumers Protection that Entrepreneurs are obligated to give compensation for the damage, taint and/or losses the consumers suffer as a result of using or consuming the goods and/or services produced or traded by the entrepreneurs Compensation shall be given within the period of 7 (seven) days after the date of transaction. It is according Article 19 Paragraph (2) that compensation shall be given within the period of 7 days, entrepreneurs does not give compensation, then dispute between customer occured. Consumers who are harmed by accusing the entrepreneurs.

Consumers dispute if entrepreneurs do not give compensation to consumers in 7 days after transaction. Dispute (conflict) consumer is a condition where consumer party wants entrepreneurs to act or do not act according what they are wanted, but entrepreneurs party refuse that request. Romy Hitijo gives explation about dispute as situation where two or more parties struggle for their own purposes where they cannot be united and on each party tries to convince other party about each truth purpose. ${ }^{15}$ Joni Emerzon gives explanation about conflict there is controversy or contradiction between parties which will be and holding relation or cooperation. ${ }^{16}$ Article 1 No. 8 Decision Letter of Miniter of Trading No. 350/MPP/Kep/12/2001 gives consumers dispute definition is dispute between entrepreneurs with consumers who sue compensation on damage, taint and/or losses who suffers as a result of using or consuming the goods and/or services produced.

Consumers dispute can be solved by Consumer Dispute Settlement Agency (BPSK) or submit it to judicial institution on where consumers located. Dispute settlement in Article 23 Law No. 8,1999 states Entrepreneurs who refuse and/or do not respond and/or do not provide compensation to the consumers' claim as intended by Article 19 Section 1, Section 2 Section 3, and Section 4 above, can be sued through the Consumer Disputes Settlement Agency or brought to court at the domicile of the consumers. ${ }^{17}$ According to two articles above, Article 23 and Article 45, then consumers dispute settlement method can be determined outside Consumer Dispute Settlement Agency

\footnotetext{
${ }^{15}$ Ronny Hanito, Hukum dan Masalah Penyelesaian Konflik, Majalah Fakutas Hukum UNDIP, Semarang, 1984, hal. 22.

${ }^{16}$ Joni Emerson, Alternatif Penyelesaian Sengketa di luar Pengadilan (negosiasi, mediasi, konsiliasi dan arbitrasi), Gramedia Pustaka, Jakarta, 2001, hal. 21.

17 Law No. 8, 1999 regardng Consumer Protection in Article 45 ;(1) Every consumer who has suffered damages may file charges against the entrepreneurs through the foundation which is responsible for settling the disputes between the on SumerS and entrepreneurs or through a court under the jurisdiction of general court; (2) Settlement of the consumers' disputes can be conducted in a court or outside the court based on the voluntary choice of the disputed parties.; (3) Settlement of the disputes outside the court as intended by Section 2 above shall not forfeit the penal responsibility as regulated in the law.; (4) If efforts to settle the consumers disputes outside the court has been made, charges can only be filed in the court if the said efforts are declared unsuccessful by one of the parties or by both of the parties in dispute.
} 
court and by law court. Dispute settlement outside court according to Article 47, it is held to achieve agreement about the form and how much loss and/or about certain act to guarantee it will not be repeated or the lost which is suffered by the consumers will not be repeated. Dispute settlement through law court according to Article 48 refers to provision about general court which is valid by concerning Article 45 . About who can accuse of entrepreneurs violation is arranged in Article $46 .{ }^{18}$

Accusation can be submitted by a group of consumers, institution of consumers or government empowering, it is submitted to general court. It means, this accusation of entrepreneur violation can be done by a consumer or heir is submitted to Consumer Dispute Settlement Agency and/or general court. Group of consumer accusation is arranged in Supreme Court Regulation No. 1, 2002 about Class Action. Class action is a prochedure of accusation submit, where one or more represent a group of many people, who has same fact or legal basis among group representative and member of group concerned. ${ }^{19}$ Consumers Protection Agency of Civil Society Organization can do legal standing, as rights of someone's accusation, a group of people or organization.

\section{CONCLUSION}

Law protection for consumer toward Bid Price and Ask Price Implementation on Airplane Ticket Purchasing basically is arranged in Ministry of Transportation Regulation No. 78, 2017, that airlines who do violation toward bid price shall be punished for Warning, Freezing, Annulment and Administration Fine. In its implementation in Manokwari, there was no pusniment given, even though there were found violation toward bid price of airline. Legal effort for consumers is for ticket price which is not according to Ministry of Transportation Regulation No. 14, 2016 that can give infomation or people complain to Ministry of Industrial and Trade or civil society organization which runs in consumer protection sector. Compensation which is eligibled if there are airlines which determine rate ouside airline ask price is material compensation proper price range and immaterial loss in form of interest from material loss which is suffered by the consumer.

Government shoud do scheduled active supervision toward airline entrepreneurs in order to give legal protection related with Bid Price and Ask Price Implementation for

18 According to provision in Article 46 paragraph (1) Charges against violations by the entrepreneurs can be filed by: a. a consumer who has suffered damages or his/her heir; b. a group of consumers who have common interests; c. a non-governmental consumer protection foundation which has met the requirements, both in the form of a legal entity or foundation, whose articles of association clearly mention that the objective of the establishment of the said organization is to protect the consumers and has conducted activities pursuant to its articles of association;

\footnotetext{
${ }^{19}$ Sudaryatmo et. al., Konsumen Menggugat, Piramedia, Jakarta, 2001, hal. 7.
} 
Airplane Ticket Purchasing, and to give firm penalty for entrepreneurs who did violation, by put compensation forward for consumers who is suffered lost. Beside that, people are suggested to deliver compain to the government to know the violation toward bid price of airline service or to submit accusation of class action which is represented to civil society organization which run in consumers protection sector.

\section{BIBLIOGRAPHY}

Abdul Kadir Muhammad, Hukum Pengangkutan Darat, Laut, Dan Udara. Bandung: PT Citra Aditiya Bakti, 2001.

Abdul Kadir Muhammad, Hukum Pengangkutan Darat, Laut, Dan Udara. Bandung: PT Citra Aditiya Bakti, 2001.

Hidayat, M. T. (2017). Perlindungan Hukum Terhadap Pengguna Jasa Angkutan Udara Dalam Perspektif Peraturan Perundang-undangan Tentang Penerbangan. Al Adl: Jurnal Hukum, 8(3).

Irianto, Sulistyowati \& Shidarta "Metode Penelitian Hukum: Konstelasi \& Refleksi", Jakarta: Yayasan Obor Indonesia, 2011.

Joni Emerson, Alternatif Penyelesaian Sengketa di luar Pengadilan (negosiasi, mediasi, konsiliasi dan arbitrasi), Gramedia Pustaka, Jakarta, 2001.

Kurniawan, K. (2012). Permasalahan dan Kendala Penyelesaian Sengketa Konsumen melalui Badan Penyelesaian Sengketa Konsumen (Bpsk). Jurnal Dinamika Hukum, 12(1), 160-172.

Muhammad, H., \& Suradi, R. N. (2016). Perlindungan Hukum Bagi Konsumen Pengguna Jasa Angkutan Umum Bus dalam Pengangkutan Orang (Studi Pada. Diponegoro Law Journal, 5(2), 1-13.

Peter Machmud Marzuki, Penelitian Hukum, Jurnal Yuridika, Vol.16, No.2, Maret 2001:103.

R. Subekti, Tanggung Djawab Pengangkut Dalam Hukum Udara Indonesia, Bandung: Eresco, 2002.

Ronny Hanito, Hukum dan Masalah Penyelesaian Konflik, Majalah Fakutas Hukum UNDIP, Semarang, 1984.

Sudaryatmo et. al., Memahami Hak Anda Sebagai Konsumen, PIRAC, Cetakan I, Jakarta, 2001.

Tim Penulis, Analisis Dan Evaluasi Hukum Tertulis Tentang Ketentuan-Ketentuan Hukum Yang Berkenaan Dengan Penentuan Jumlah Ganti Rugi Dalam Bidang Pengangkutan Udara, Jakarta: Badan Pembinaan Hukum Nasional Departemen Kehakiman, 2013. 